\title{
Improving early childhood teachers' formative assessment practices: Transformative role of collaborative action research
}

\author{
Selda Aras $^{* a}$ \\ ${ }^{a}$ Başkent University, Faculty of Education, Ankara /Turkey
}

Article Info

DOI: $10.31704 /$ ijocis.2019.010

Article History:

Received 02 May 2019

Revised 05 August 2019

Accepted 09 August 2019

Online 26 December 2019

\section{Keywords:}

Formative assessment,

Collaborative action research,

Portfolio,

Early childhood education.

Article Type:

Research paper

\begin{abstract}
The aim of this study is to investigate the change process of early childhood teachers' formative assessment practices via collaborative action research. Formative assessment contributes to children's development and learning process and also guides teachers on instructional decisions. Although research emphasizes the importance of formative assessment, teachers encounter difficulties while implementing it in their classrooms. Three early childhood teachers participated in this qualitative study, and the data were gathered through interviews and observations. The findings about the teachers' change processes revealed that despite the difficulties experienced; teachers began to conduct systematic observation, document children's development and learning, and use assessment data for their further plans. The transformative power of action research in changing teachers' practices is highlighted in this study.
\end{abstract}

\section{Okul öncesi öğretmenlerinin biçimlendirici değerlendirme uygulamalarının geliştirilmesi: İşbirlikçi eylem araştırmasının dönüştürücü rolü}

Makale Bilgisi

DOI: $10.31704 /$ ijocis.2019.010

Makale Geçmişi:

Geliş $\quad 02$ Mayıs 2019

Düzeltme 05 Ağustos 2019

Kabul $\quad 09$ Ağustos 2019

Çevrimiçi 26 Aralık 2019

Anahtar Kelimeler:

Biçimlendirici değerlendirme, İşbirlikçi eylem araştırması, Portfolyo,

Erken çocukluk eğitimi.

Makale Türü:

Özgün Makale

\section{Öz}

$\mathrm{Bu}$ çalışmanın amacı, işbirlikçi eylem araştırması yoluyla okul öncesi öğretmenlerinin biçimlendirici değerlendirmeye yönelik uygulamalarındaki dönüşüm sürecini araştırmaktır. Biçimlendirici değerlendirme, çocukların gelişim ve öğrenme süreçlerine katkıda bulunmakta ve öğretmenleri öğretim kararları konusunda yönlendirmektedir. Araştırmalar tarafından biçimlendirici değerlendirmenin önemini vurgulanmakla birlikte, öğretmenlerin uygulamalarında güçlüklerle karşılaştıkları bilinmektedir. Bu çalışma üç okul öncesi öğretmeninin biçimlendirici uygulamalarının geliştirilmesi amacıyla gerçekleştirilmiştir. Öğretmenlerin dönüşüm süreçleri, nitel bir araştırma tasarımıyla ayrıntılı bir şekilde sunulmuştur. Araştırma bulguları öğretmenlerin sistematik gözlem gerçekleştirdiklerini, gözlemlerini dokümente ettiklerini ve değerlendirme verilerini ileriki planları için kullanmaya başladıklarını göstermektedir. Eylem araştırması sürecinin öğretmen uygulamalarını dönüştürücü rolü bu çalışma ile vurgulanmaktadır. 


\section{Introduction}

In its broad definition, assessment is a process for gathering information to make decisions about children's development and learning, instruction, programs, and interventions (Carr, 2001; Mindes \& Jung, 2015; Wortham, 2011). The role of formative assessment is increasingly recognized as important for providing guidance and feedback to teachers and learners for a meaningful instruction. Formative assessment is not only assessment but also a mean for learning; it is an essential piece of effective pedagogy. When applied to young children, assessment should provide a rich picture of the ways in which they learn, think, and act (Bowman, Donovan, \& Burns, 2001; Twombly, 2014).

Formative assessment is a process that informs and supports teaching while learning is taking place (Black \& Wiliam, 1998; Heritage, Kim, Vendlinski \& Herman, 2009). Shepard (2009) asserted that assessment should be placed in the center of the teaching and learning process instead of being conducted at the end of the instruction. Systematic, ongoing assessment of learning has become a critical characteristic of high-quality programs (Donovan, Bransford, \& Pellegrino, 2000). Recent research reports that formative assessment is a fundamental strategy for improving student learning (Dunn \& Mulvenon, 2009; Hattie \& Timperley, 2007; McMillan, Venable \& Varier, 2013). Authors of a longitudinal research project assert that the importance of formative assessment depends on how it meets children's needs and supports their learning (Siraj-Blatchford et al., 2002). The contributions of formative assessment to the teaching process are so great that Black (2001) recognizes it as a tool for educational reform. The evidence obtained from formative assessment practices has an impact on the adaptation of teaching so as to meet children's needs (Black, Harrison, Lee, Marshall \& Wiliam, 2004). Especially in early childhood settings, teachers need more curriculum-embedded assessment strategies to meet complex learning processes of young children. Formative assessment also enables teachers to provide effective feedback during learning moments. In addition to research studies, the National Association for the Education of Young Children, the National Council of Teachers of English, and the National Council of Teachers of Mathematics have long promoted the use of formative assessment early childhood in learning contexts.

Observation is the cornerstone of the formative assessment process and is seen as the foundation of all assessment techniques (Gullo \& Ambrose, 1987; Wortham, 2012). During observations teachers purposefully document evidence of children's learning and development via multiple tools. Teachers make decisions based on their observations during their many hours with students and decide about what and how to teach and which materials to use. They make decisions about both the children's and their own roles during activities. They analyze children's interactions and decide how to provide feedback and guide their learning experiences. Early childhood professionals view classroom observation based on specific criteria as one of the best methods for determining a child's strengths and weaknesses (Seefeldt, 1998). Observation is also recognized as a valuable way to gather information about students' progress and to become aware of children's individual characteristics (Wortham, 2012). Children's natural behaviors in a normal setting provide more important clues about their development than formally designed assessments or instruments (Beaty, 2012). Especially during the early years, when children are unable to express themselves fully with words, observation is eminently valuable.

Though the theoretical contributions of formative assessment are well documented in the literature, especially in early childhood learning environments, there are limited studies on this critical issue. Formative assessment is also theoretically highlighted in teacher education and training programs, yet it is also pointed out that teachers do experience difficulties and conflicts while practicing it to support learning (Black \& William, 2005; Yin \& Buck, 2019). Existing studies indicate that teachers do not feel confident implementing formative assessment in their classrooms (Aydın, 2005; Çakan, 2004; Pilten, 2001). Planning instructions based on assessment information is difficult (Heritage, Kim, Vendlinski, \& Herman, 2009; Schneider \& Meyer, 2012) and is a complex process (Vinglese, 2014). The tendency on summative assessment hinder curriculumembedded assessment (Bennett, 2011; William, 2006). Some studies report that the formative assessment process can be extremely confusing to teachers (Ruiz-Primo \& Furtak, 2006; Wininger \& Norman, 2005).

In response to these difficulties, researchers have recommended professional development to increase teachers' understanding and practice of formative assessment (Dixon, 1999; Hill, 2000). Shepard (2000) suggested that teachers need professional guidance and assistance while learning to implement formative assessment in their classrooms. There is also a lack of research examining how to effectively help teachers implement a high-quality formative assessment practice and the role of professional development models on 
formative assessment and their impact on both teacher practice (Andersson \& Palm, 2018; Schneider \& Randel, 2010). Limited research on this issue indicated that teacher learning on assessment account for teacher implementations on assessment for learning (James \& Pedder, 2005). Aschbacher and Alonso (2006) indicated that when teachers use formative assessment to understand student thinking, they increase children's learning. Supporting this idea through their mixed methods study, Ruiz-Primo and Furtak (2006) concluded that informal formative assessment is beneficial when teachers understand it as a process and use this process to adjust their plans. In the light of research, this study aimed to investigate the change process of early childhood teachers' formative assessment practices via collaborative action research design.

The current research questions are:

- What are the changes in early childhood teachers' practices as teachers learn how to practice formative assessment?

- How can formative assessment practices improve early childhood teachers' instructions?

\section{Method}

This research was qualitative in nature and was undertaken as a collaborative action research design aiming to improve the practices of teachers. Action research is a way that teachers participate in an authentic professional learning process which improves their classroom practices (Darling-Hammond, Wei, Andree, Richardson, \& Orphanos, 2009; Ryan, et. al., 2017; Somekh \& Zeichner, 2009). The aim of action research is to improve the quality of organizations, families, or schools (Stringer, 2007). The researcher engages in the process and participants to improve their practices and tries to contribute to change in the classrooms (Creswell, 2012).

Among the types of action research, collaborative action research provides a culture of "shared expertise" (Mitchell, Reilly \& Logue, 2009) for the improvement of practice. The collaboration with researchers and teachers have an essential role in bridging theory and practice for the enhancement of instruction. The type of professional development is needed to be "closer" and the nature of the connection between researchers and teachers should be meaningful and applicable for classroom teaching (Cochran-Smith, 1991; Mitchell, Reilly \& Logue, 2009). Collaborative action research enables teachers to collaborate with different stakeholders as coresearchers for a new climate of inquiry.

A successful collaborative action research relationship established with university researchers as mentors or critical friends (Kember et al., 1997) can inform teachers' pedagogic practice in the classroom; and can provide support for their professional development and learning (Mitchell, Reilly, \& Logue, 2009). The researcher engages in the process and participants to improve their practices and tries to contribute to change in the classrooms (Creswell, 2012).

The study took place in a preschool located in Ankara, Turkey. The motivation of this study began after a teacher training seminar at the beginning of the academic year. I met with teachers and conducted meetings on the topics to be covered through these pieces of training. During our meetings, it was obvious that teachers need additional knowledge on assessment implementations. Research questions of the study were formulated during these meetings conducted with teachers. In this study, the aim is to change practices of early childhood teachers on formative assessment and enable them to use formative assessment to guide their further plans. My role in the study, as a teacher educator, was mentoring teachers through their formative assessment practices. At the beginning of the process informed consent was obtained from participant teachers. The inservice teachers at this preschool were the participants of the study. There were three participants of the study. Two of the teachers were experiencing the first years of their teaching life, the second year as another teacher. Participant teachers are graduates of two-years early childhood teacher education programs. The teachers did not receive any training for assessment and stated that they found themselves insufficient in the assessment practices.

I visited teachers in their classrooms, made observations, and took field notes. At the end of the training, I conducted interviews with teachers again about their experiences. Data were gathered through semistructured interviews and observations conducted in each classroom in the study. Each teacher was visited once a week for a total of 10 weeks. Each field visit took approximately 50-60 minutes. At the end of the procedure, each teacher was interviewed related to their experiences on formative assessment. 
For the data analysis of the study, an inductive approach based on constant comparative data analysis method was followed (Strauss and Corbin, 1998). The data were coded in the first stage by structured coding. In this process, researcher have analyzed initial codes by reading the interview solutions and field notes. In the second stage, the relation of the obtained codes with each other was examined and re-coded and categories were generated by axial coding (Saldana, 2016). The analysis process was ended by unifying codes under more inclusive themes.

Some strategies were employed by the researcher to address credibility and trustworthiness of the study. Triangulation was one of the strategies among the multiple data sources used to draw conclusions. Prolonged engagement and persistent observation were also utilized for the credibility of the study (Lincoln \& Guba, 1985). Adequate time was spent in collecting data, understanding of the practices of participants and persistent observation was conducted for the depth of the study. The study also provides a description of the strategies and rich quotes from the participants for the credibility of the study (Merriam, 1998).

Action research has a spiral of reflective cycle including planning, acting and observing, and reflecting steps (Kemmis \& McTaggart, 2000). Figure 1 demonstrates the reflective cycle of this study.

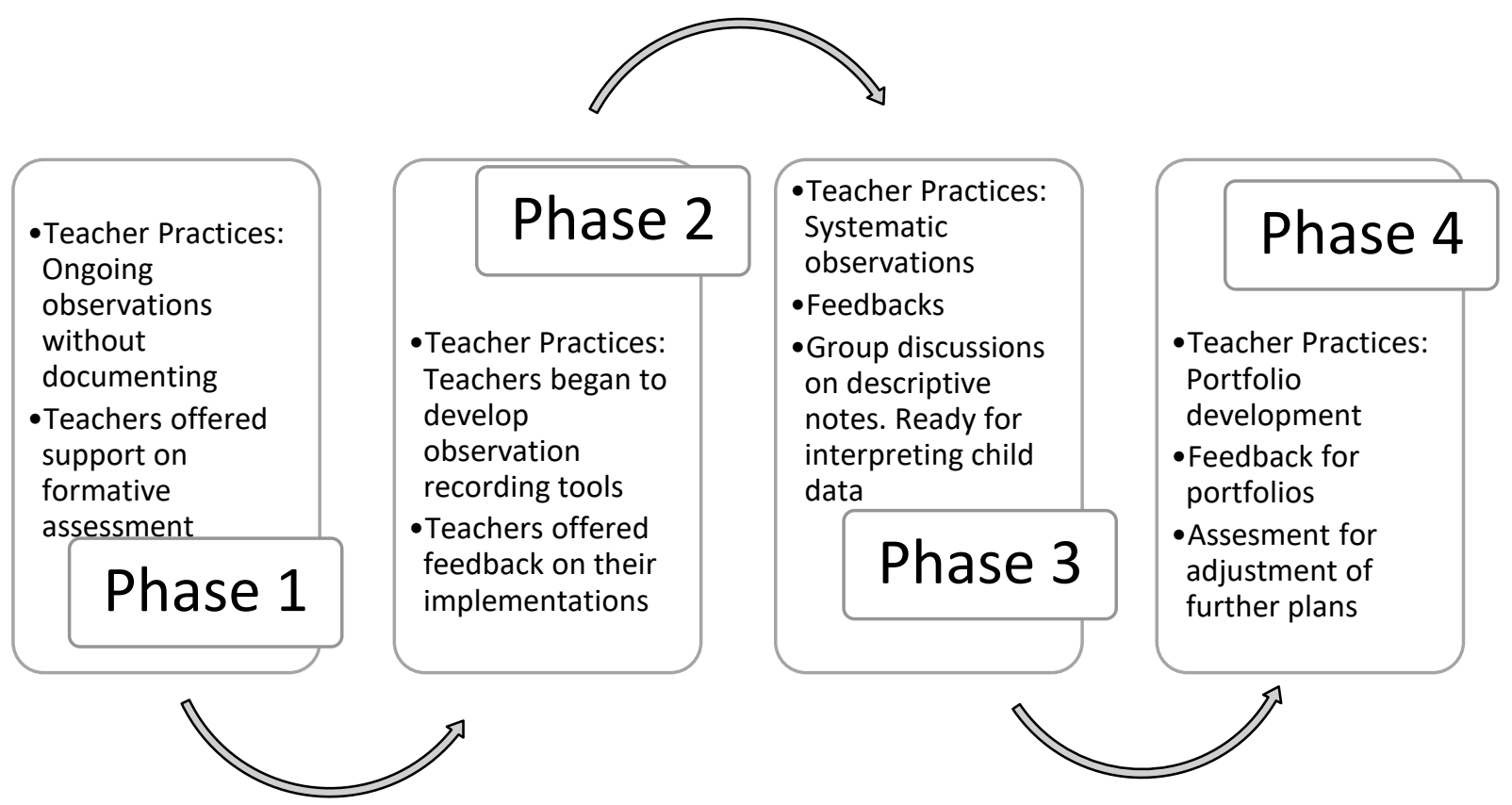

Figure 1. The reflective cycle of the collaborative action research.

Phase 1: In the first phase of the study the teachers were provided in-service teacher trainings on formative assessment; including observation, observation tools, data gathering from children, interpretation and sharing the data with stakeholders, making decisions for further teaching. After this training I conducted observations in three classrooms and took field notes about their assessment practices. Three of the teachers stated that they recognized the role of assessment for learning but got difficulty on practicing it in their real classrooms. Teachers were only conducting ongoing observation. Teachers offered for a new training on assessment tools. We decided a meeting for discussing and reflecting on their experiences.

Phase 2: We conducted a meeting with the teachers on their assessment practices together. Teachers complained about the difficulty of making systematic observation and gathering data from children. We conducted discussions with concrete samples of observation tools that I had provided for them. We discussed on the role of obtained data through the assessment tools on their planning and teaching. This phase ended with teachers' decision on preparing their own observation recording tools and using them in their classrooms. 
Phase 3: Teachers began to conduct systematic observation. Throughout my observations in their classrooms, I saw different data gathering tools on their tables and/or folders. They asked for feedback for their tools, so we conducted mini-meetings on each of their experiences. We also discussed about their observations and taking meaningful and effective anecdotal records. Teachers reflected on that they used the observational data in their decisions about children's learning and development. Teachers felt ready to gather their recordings in a portfolio.

Phase 4: Teachers organized individual children's portfolios with the engagement of children into decisionmaking processes of their own portfolios. Teachers began to use assessment data for their further plans.

Results

\section{The value of systematic observation and documentation for formative assessment}

In the beginning, we realized a need to improve observation practices for an effective formative assessment. My first observations also pointed out that teachers' sole assessment practice was photographing. They were only conducting ongoing observations and taking photographs of children during their activities to be sent to parents. They were not taking any anecdotal records or recording observational notes. They were also not using any assessment tool for monitoring children's development and learning. Teachers asked for a meeting on assessment tools at which we discussed their classroom implementations. I asked each of the teachers about their observations and gave concrete examples of how to record their observations. Since they asked me for samples of observation recording tools provided samples for recording observations such as checklists, rubrics, anecdotal records. Teachers reflected on that they felt more confident after seeing the samples. We discussed the role of obtained data through the assessment tools on their planning and teaching. They stated that the plans that include these tools would be different from their ordinary plans as it would be a guide for them about children's development and learning. This phase ended with teachers' decision on preparing their own assessment tools and using them in their classrooms. Teachers began to develop assessment tools. Throughout my observations in their classrooms, I saw different data gathering tools on their tables or folders. Teachers were developing developmental checklists, taking observational notes, and capturing children's photographs that reflect their any learning moment.

The data of the study revealed that teachers became more systematic during their observations. In the first weeks of the field visits, teachers were conducting only observations that are not systematic. However, as the trainings went on, their practices of systematic observation and observation gathering tools improved. The teacher 1 stated formative assessment guided her to be more systematic and supported her observation implementations. Among assessment tools that she used she expressed that anecdotal records and narrative notes were very beneficial for her. She asserted that descriptive assessment tools were valuable in terms of being aware of the progress of each child and also the whole children in the classroom. In the words of her: "I wrote some things (evidences) that reflect children's learning and it is also useful for our own development. For instance, while I was recording A.'s (a child's name) indicators, we experienced a progress which occurred step by step. I was systematically recording A.'s development and learning evidences and then change or revise my teaching strategies or materials in order to support his development. But then I realized that this progress was not seen regarding with some other children in the classroom. Those children were the ones that I wrote anecdotal records less."

Teacher 2 told that it was not possible for making plans without observations. She stated that at the beginning of the semester she did not take any observational notes and assessed children's development and learning based on what she remembers. She added that "After these practices, I recognized that to be more systematic, I should take notes and record what I have observed in the classroom."

Teacher 3's quotations also indicated that her awareness of the crucial contribution of the observation process on teaching and learning improved. She further pointed out that "Observation is about knowing children into the light in their eyes. Observation makes us visualize the whole process in the classroom and the teachers' practices. It is a system that makes everything (experienced in a classroom) visible and clear." The teacher noted that at the beginning of the process she encountered the difficulty of taking observational notes while making an activity with children. She reflected on her own learning process through the action research phases and defined how she was able to improve her skills by implementing formative assessment. In the 
words of her, "Now I know that it is effective to record evidences of children's learning, it is important to take notes when I catch a child demonstrating a specific learning goal."

\section{Formative assessment as a guiding tool for valuing children's voice on further planning}

The participant teachers began this process expecting the formative assessment to be a tool for increasing children's voice and responding to children's needs. During my beginning observations, I realized that teachers' practices were quite far away from assessment-embedded instructions. Teachers only asked question for children at the end of the activities to assess their learning. During our planning and reflecting sessions, teachers agreed that they had to reconstruct classroom experiences in order to integrate formative assessment. It was evident that teacher-centered activities do not allow teachers conduct formative assessment. Teachers designed less structured activities for children and tried to be a "guide" instead of "lecturer" during classroom activities. This child-centered manner allowed teachers to listen to children and consider children's voice in their instructional decisions. The teacher 3 emphasized on her point of view regarding with children in the classroom. She asserted that she took the children on the center of the curriculum and reflected on previous activities. She stated that "I was deciding on an activity to be completed in a predetermined time and was forcing children to complete their works, then I told myself that I should stop, listen to children, and consider what or how they want to do."

Participants pointed to contribution of formative assessment that it changed the point of the teacher through being more child-centered. Teacher 3 said that, "I will consider children's needs more, I want to move on their needs more after this process." She also emphasized the value of interpretations of teachers on children's development and learning after gathering data from children through variety of assessment tools. In the words of her, "It is important to assess children's development and learning, but it is not the case. We should contribute them (children's development and learning) depending on our assessments."

Observations and interviews conducted with the participant teachers indicated that teachers had recognized the importance of assessment for further planning. The observations revealed that teachers became to use their assessment data for their lesson plans. Teachers observed as referring to their observational notes and making decisions on their implications based on these notes. An important issue that emerged from the teacher 1's perspective of the value of formative assessment was that it guided her instructional plans. The teacher noted that formative assessment practices helped her decide where the classroom experiences should go next: "I will make my plans through children's needs and interests, I will be more systematic." She also asserted that it is important after now to consider children's developmental needs and decided on activities that will support those needs. She stated that through an examination of multiple assessment tools she was able to reflect on the ways for improving children's learning.

Teacher 2 reported that formative assessment data provided them with information on children's learning and development. She noted that formative assessment was part of the instructional process. She believed that there is a need to ensure that the instructional process meets the needs of each child. She compared her previous implementations in terms of making plans and stated that "I was looking for ready activities and implementing them in classroom and if many of the children were happy with the activities then I would be happy too... However, now I know that it should be more child-centered."

Teachers' awareness of the importance of gathering meaningful data from children to guide their plans was increased. For instance, teacher 1 stated that at the beginning of the semester, she was only noting down the responses of children to her specific questions related to the classroom activities. She added that "I realized that I should also note their statements, quotations during their interactions or while they are working on an activity as well as their responses to my questions."

Observations and interviews indicated that formative assessment implementations enabled teachers to improve their teaching practices. An important issue that the teachers commented on the value of formative assessment was that it modified and improved their teaching. For example, teacher 3 reflected on her experiences and noted that "I think on what to do after taking observational notes. Especially, when I observed a negative aspect in the classroom I began to decide on ways of improving my implementations." Teacher 2 also pointed that formative assessment enabled her to act in a more evidence-based manner. She said that "I like the process as it is evidence-based, it allows us to demonstrate evidences (of children's development and learning)". 


\section{Portfolio as a complementary reflective tool for formative assessment practices}

In the beginning, teachers' portfolio implementations were limited to children's artifacts and products. All members of the collaborative team agreed that portfolio is a strong documentation tool for formative assessment and decided that existing portfolios of the participant teachers should be improved. The existing portfolios were not providing a holistic picture of children's development and learning. We realized that along with implementing formative assessment, we had to reconstruct portfolio as a documentation tool and reflective practice. We expanded a lot of effort in our meetings in terms of organizing portfolio with the collected data during systematic observation to be shared with children, parents, and teachers. Teachers were suggested to use multiple tools and methods, such as anecdotal records, observational notes, checklists, rubrics, capturing learning moments of children by photographs, and children's portfolios, to assess young children's learning and development. Teachers systematically gathered evidence of children's development and learning in children's individual portfolios. Children's portfolios included multiple observational tools and notes that they gathered during their systematic classroom observations. Each child's portfolio included multiple evidences for each developmental area. Teachers collected anecdotal records, photographs of learning experiences, checklists, observational notes, and child artifacts and products in the portfolios. Teachers organized individual children's portfolios with the engagement of children into the decision-making processes of their own portfolios. Feedbacks were provided for teachers' portfolio contents and teachers made evaluations regarding with the children's learning and their classroom practices.

Teachers especially exemplified portfolios and asserted how a holistic portfolio enabled them to decide on whether adjustments were needed in her teaching. Teacher 2 stated that "I see what I should do to cover the holistic view of the development. I looked at the portfolio and recognized if there is something missed in the curriculum or decided on the issues to be considered." She also noted that when she evaluated the portfolios she realized that most of the children had selected early literacy activities to be included in their portfolios which is an indicator that those activities had made sense on children.

Participant teachers also commented on contributions of portfolio on their implementations in terms of engaging children to the decision making processes of their activities. During the observations conducted in the classrooms it was seen that teachers provided opportunities for children to revisit and reflect on their learning. Especially, in their portfolio implementations, they asked children to decide on the artifacts and products they wanted to include in it. Teacher 2 stated that inviting children for the assessment process enabled her to see what the learned. It is emphasized that re-visitations done by children were valuable in terms of enhancing previous learning experiences.

\section{Discussion, Conclusion and Implications}

Teachers' participating in the study described formative assessment as a guide for their instructional plans. Consistent with the findings of Torrance and Pryor (2001), the present study confirmed that formative assessment enabled teachers to improve their teaching practices. The implementation phases of formative assessment were initially the emergence of self-awareness of teachers on their existing practices. According to Torrance (2001), pedagogical self-awareness is the important point for effective formative assessment experiences. As teachers experienced formative assessment in a collaborative action research period, they initially recognized their practices and reflected on them. Then they came to recognize that formative assessment is potentially more effective in supporting instructional processes in the classroom (Black \& Wiliam, 2009; Shepard, 2000). This study highlighted that formative assessment is a crucial way for assessment for learning. It helped teachers to adjust their decisions on instructional plans. Teachers emphasized that formative assessment was effective in identifying children's needs and adjusting their teaching accordingly. Teachers were able to see the impact of differencing experiences on the progress of children's' learning. Consistent with the findings of Buldu (2010), formative assessment informed teachers about children's learning experiences and the systematic collection of data gathered from children served as a tool to be used for instructional purposes. Adapting instructional strategies and pedagogical decision making to children's needs and interests requires a comprehensive knowledge and skill base. Besides, research on intentional teaching highlight the effect of intentional teaching on positive teacher-child relationship (McLaughlin, Aspden \& Snyden, 2016). 
The findings of the study also revealed that the practice of formative assessment enabled teachers to listen to children. The study conducted by Sak, Tantekin-Erden, and Morrison (2018) found Turkish teachers' assessment practices as being inappropriate in terms of child-centeredness. This present study indicates that collaborative action research can be a valuable tool to improve teachers' child-centered assessment implementations. Teacher participants of this study stated that they started to listen to children and hear them more and give them the opportunity to assess their own learning. Black and Wiliam (2009) emphasized activating children as the owners of their own learning as a strong aspect of formative assessment practices.

Another important finding of the study was the transformation of portfolio practices in each classroom. It was observed that a holistic portfolio also provided a strong platform for children's voice. Teachers' portfolio implementations invited children to the process and portfolios with multiple tools helped children to remember and revisit their previous learning experiences. Portfolios also provided teachers the opportunity to systematically document each child's learning and development and drawing conclusions. Research also recommends teachers to use portfolios to enhance children's classroom experiences and support teachers' practices (Laski, 2013; Seitz, 2008). The portfolio is an archive for a child's progress over a period of time, supports children's past experiences, supports teachers' assessment practices, and is an effective tool for communication with families.

The process in this study enabled teachers to have a professional look of what they have seen, to assess children's development and learning, and provide direction for the curriculum implementation, as this issue has been emphasized in the literature (Morrison, 2012). Teachers in the present study also commented on the role of systematic observation on their classroom experiences. A systematic and purposeful observation will be helpful for curriculum planning and instructional strategies which will be used by the teachers (McAfee \& Leong, 2011). Research conducted with early childhood teachers on assessment practices also reveal that teachers mostly benefit from observation in the assessment of children (Hanes, 2009; Koçak, 2005; Schappe, 2005; Sezer, 2010). Teachers view of observation was as a valuable tool to see the child as a whole and to see many components at the same time (Schappe, 2005). Studies conducted on pedagogical documentation as a formative assessment tool (Buldu, 2010; MacDonald, 2007) also revealed the essential role of observation and documentation process on teachers' instructional decisions. The findings of this study also indicated that formative assessment practices enabled not only to monitor children's learning but also to evaluate their own instructional practices. They emphasized the role of formative assessment to be aware of their practices and guide them to decide on whether adjustments were needed in her teaching. It is important for assessment practices to be used to examine and improve teaching practices (Shepard, 2009).

This present study aimed to contribute to the literature in terms of the benefits of formative assessment in early childhood settings and the importance of collaboration between researchers and teachers. Formative assessment, which is an under-researched issue, is encountered by teachers as difficult to implement and teachers seem to be confused by its complex process. However, within this study, it is asserted that with a professional collaboration, teachers are able to implement this assessment procedure in their classrooms and interpret the assessment data for adjustment of new plans.

Research focuses on teacher knowledge and learning on formative assessment and suggest professional development activities for teachers to improve their formative assessment practices (Black \& Wiliam, 2009; Shepard, 2000). This study used collaborative action research to improve teachers' practices and the findings indicated participant teachers' progress on their formative assessment experiences. Research indicated that formative assessment practices challenge teachers and are not often used by teachers (Aydın, 2005; Çakan, 2004; Pilten, 2001; Shepard, 2000). This study revealed that teachers can apply formative evaluation practices in their classes with the process of action research. In this case, if support is provided to the teachers, they can not only improve themselves in terms of assessment but also the whole classroom experiences. Teachers need professional help and knowledge to implement formative assessment in their classrooms (Bennett, 2011). Collaboration between researchers and teachers have a strong potential to affect teachers' practices and result with improved achievement (Tayler, 2012) Then, the transformative power of action research in changing teachers' approaches can be highlighted through this present study as it was mentioned by Pine (2009). Action research studies conducted with teachers also pointed on the critical contribution of action research on teachers' improvement regarding with their classroom implementations (Pine, 2009). 
Assessment has a critical role in teaching and learning, especially in early years. Young children's development and learning process is complex and is difficult to be assessed through summative and traditional methods. Teachers need more curriculum-embedded strategies while working with young children. Systematic observation, multiple tools to record pieces of evidence of development and learning, purposeful documentation, interpretation of the gathered data and using assessment data for further planning are fundamental characteristics of formative assessment. It is asserted by research that teachers need to improve their assessment practices. Through this study collaborative action research is recommended as a method for supporting teachers' professional learning on formative assessment. Teachers are invited to use assessment for learning instead of assessment of learning in early years. Implementing a holistic child portfolio is also suggested for early childhood teachers. Portfolios are valuable tool for monitoring children's progress, evaluating program implementations, and informing parents about children's development and learning.

The scope of this research is limited with teacher implementations and perceptions on formative assessment without investigating the role of formative assessment on children's development and learning. This research lacks examining how the process resulted from the children's side. It is crucial to investigate the impacts of formative assessment practices in early year's development and learning.

Research assert the role of professional development designs for assessment for learning. It is needed to investigate the professional needs of teachers on their assessment practices and develop professional development models to meet their needs and contribute to their practices. Longitudinal research is needed to study with more teachers and improve their practices on formative assessment. Particularly in national context, robust studies, that will serve to raise the importance of formative assessment, are needed both to investigate early childhood teachers' formative assessment practices and be responsive to their professional needs and provide necessary assistance for their classroom implementations. 


\section{TÜRKÇE SÜRÜM}

\section{Giriş}

Değerlendirme, en geniş tanımıyla, çocukların gelişimi ve öğrenmesi, öğretim süreçlerinin programlanması ve sınıf içi müdahaleler hakkında karar vermek için bir bilgi toplama, yorumlama ve paylaşma sürecidir (Carr, 2001; Mindes \& Jung, 2015; Wortham, 2011). Öğretmenlere ve öğrenenlere rehberlik ve geri bildirim sağlayan biçimlendirici değerlendirmenin, bir diğer adıyla öğrenme için değerlendirmenin önemi giderek artmaktadır. Biçimlendirici değerlendirme sadece değerlendirme değil, aynı zamanda öğrenme için bir araçtır; bu etkili bir pedagojinin temel bir parçasıdır. Küçük çocuklara uygulandığında değerlendirme, öğrenme, düşünme ve davranış biçimlerinin zengin bir görüntüsünü sağlamalıdır (Bowman, Donovan \& Burns, 2001; Twombly, 2014).

Biçimlendirici değerlendirme, öğrenme sırasında gerçekleşen, öğretim süreçlerine rehberlik eden ve bu süreçleri destekleyen bir yöntemdir (Black \& Wiliam, 1998; Heritage, Kim, Vendlinski \& Herman, 2009). Shepard (2009), değerlendirmenin öğretim sonunda yapılmak yerine, öğretme ve öğrenme sürecinin merkezine yerleştirilmesi gerektiğini ileri sürmüştür. Sistematik bir şekilde devam eden öğrenmenin değerlendirilmesi, yüksek kaliteli programların kritik bir özelliği haline gelmiştir (Donovan, Bransford \& Pellegrino, 2000). Öğrenme sürecinin merkezinde yer alan bu değerlendirme türü eğitim reformu için bir araç olarak kabul edilir (Black, 2011). Son araştırmalar, biçimlendirici değerlendirmenin çocukların gelişim ve öğrenmesini iyileştirmek için temel bir strateji olduğunu bildirmektedir (Dunn \& Mulvenon, 2009; Hattie \& Timperley, 2007; McMillan, Venable \& Varier, 2013). Biçimlendirici değerlendirmenin önemi çocukların intiyaçlarına cevap vermesi ve gelişim ve öğrenmelerini desteklemesinden kaynaklanmaktadır (Siraj-Blatchford et. al., 2002). Biçimlendirici değerlendirme uygulamalarından elde edilen kanıtlar ve bilgiler, çocukların gereksinimlerini karşılamak için öğretimin adaptasyonu üzerinde etkilidir (Black, Harrison, Lee, Marshall \& Wiliam, 2004). Özellikle erken çocukluk ortamlarında, öğretmenlerin küçük çocukların karmaşık öğrenme süreçlerini karşılamak için daha fazla müfredata gömülü değerlendirme stratejilerine ihtiyacı vardır. Biçimlendirici değerlendirme aynı zamanda öğretmenlerin öğrenme anlarında etkili geri bildirim almalarını sağlamaktadır.

Biçimlendirici değerlendirme uygulamalarının önemli unsurlarından birisi sistematik gözlemdir. (Gullo \& Ambrose, 1987; Wortham, 2012). Gözlemler sırasında öğretmenler, çocukların öğrenme ve gelişme kanıtlarını birden fazla araçla amaçlı bir şekilde kayıt altına almaktadır. Öğretmenler, çocuklara yönelik uzun saatler boyunca gözlemlerine dayanarak kararlar alırlar ve neyi, nasıl öğreteceklerini ve hangi materyallerin kullanılacağına karar verirler. Sınıf içi deneyimler sırasında hem çocukların hem de kendi rolleriyle ilgili kararlar alırlar. Çocukların etkileşimlerini analiz eder ve nasıl geri bildirim vereceğine ve öğrenme deneyimlerine nasıl rehberlik edeceğine karar verir. Erken çocukluk profesyonelleri, sınıf içi gözlemleri, bir çocuğun güçlü ve zayıf yönlerini belirlemek için en iyi yöntemlerden biri olarak belirli kriterlere göre görürler (Seefeldt, 1998). Gözlem ayrıca çocukların ilerlemesi hakkında bilgi toplamanın ve çocukların bireysel özelliklerinin farkında olmanın değerli bir yolu olarak kabul edilmektedir (Wortham, 2012). Normal bir ortamda çocukların doğal davranışları, onların gelişimi hakkında resmi olarak tasarlanmış değerlendirmelerden veya araçlardan daha önemli ipuçları sağlar (Beaty, 2012). Özellikle çocukların ilk yıllarında, çocukların kendilerini kelimelerle tam olarak ifade edemedikleri durumlarda, gözlem çok önemlidir.

Biçimlendirici değerlendirmenin teorik katkıları alanyazında, özellikle de erken çocukluk dönemi öğrenme ortamlarında vurgulanmasına rağmen, bu kritik konuda sınırlı çalışmalar bulunmaktadır. Biçimlendirici değerlendirme aynı zamanda öğretmen eğitimi ve öğretim programlarında teorik olarak vurgulanmaktadır, ancak öğretmenlerin öğrenmeyi desteklemek için uygularken zorluklar ve çatışmalar yaşadıkları da belirtilmektedir (Black \& William, 2005; Yin \& Buck, 2019). Mevcut araştırmalar, öğretmenlerin sınıflarında biçimlendirici değerlendirme uygulamaları konusunda kendilerini yeterli hissetmediklerini göstermektedir (Aydın, 2005; Çakan, 2004; Pilten, 2001). Değerlendirme bilgilerine dayanarak planlama yapmanın zor olduğu öğretmenler tarafından belirtilmektedir (Heritage, Kim, Vendlinski \& Herman, 2009; Schneider \& Meyer, 2012) ve karmaşık bir süreçtir (Vinglese, 2014). Sonuç odaklı değerlendirmeye yönelik eğilim, müfredata gömülü değerlendirmeyi engellemektedir (Bennett, 2011; William, 2006). Bazı çalışmalar biçimlendirici değerlendirme sürecinin öğretmenler için son derece kafa karıştıııcı olabileceğini bildirmektedir (Ruiz-Primo ve Furtak, 2006; Wininger \& Norman, 2005). 
Bu zorluklara cevap olarak, araştırmacılar öğretmenlerin biçimlendirici değerlendirme anlayışını ve pratiğini arttırmak için mesleki gelişim önermektedir (Dixon, 1999; Hill, 2000). Shepard (2000), öğretmenlerin sınıflarında biçimlendirici değerlendirme yapmayı öğrenirken profesyonel rehberliğe ve yardıma ihtiyaç duyduklarını önermiştir. Ayrıca öğretmenlerin yüksek kaliteli bir biçimlendirici değerlendirme uygulaması ve mesleki gelişim modellerinin biçimlendirici değerlendirme üzerindeki rolünü ve her iki öğretmen uygulaması üzerindeki etkilerini etkili bir şekilde nasıl kullanabileceklerini inceleyen bir araştırma eksikliği de bulunmaktadır (Schneider \& Randel, 2010; Andersson \& Palm, 2018). Bu konuda yapılan sınırlı araştırma, öğretmenlerin değerlendirme uygulamalarının geliştirilmesinin uygulamalarına yansıdı̆̆ını göstermektedir (James \& Pedder, 2005). Aschbacher ve Alonso (2006) öğretmenlerin öğrenenlerin düşünmesini anlamak için biçimlendirici değerlendirme kullandıklarında, çocukların öğrenmelerini artırdıklarını belirtmişlerdir. Bu düşünceyi karma yöntemler çalışmalarıyla destekleyen Ruiz-Primo ve Furtak (2006), öğretmenler bunu bir süreç olarak anladıklarında ve bu süreci planlarını ayarlamak için kullandıklarında biçimlendirici değerlendirmenin yararlı olduğu sonucuna varmışlardır. Araştırmalar ışığında, bu çalışma, erken çocukluk dönemi öğretmenlerinin biçimlendirici değerlendirme uygulamalarının değişim sürecini işbirlikçi eylem araştırması tasarımı ile incelemeyi amaçlamıştır.

Araştırma soruları:

- Okul öncesi öğretmenlerinin eylem araştırması süreci ile birlikte biçimlendirici değerlendirme uygulamalarındaki değişiklikler nelerdir?

- Biçimlendirici değerlendirme uygulamaları, okul öncesi öğretmenlerinin öğretim süreçlerini nasıl geliştirmektedir?

\section{Yöntem}

Bu araştırma öğretmenlerin uygulamalarını geliştirmeyi amaçlayan nitel bir çalışma olarak tasarlanmıştır. Eylem araştırması, öğretmenlerin sınıf uygulamalarını geliştiren gerçek bir profesyonel öğrenme sürecine katılmasının bir yoludur (Darling-Hammond, Wei, Andree, Richardson \& Orphanos, 2009; Ryan et. al., 2017; Somekh \& Zeichner, 2009). Eylem araştırmasının temel amacı, öğretmen uygulamalarının, ailelerin veya okulların kalitesini arttırmaktır (Stringer, 2007). Araştırmacı bu süreçte, uygulamalarını geliştirmek için sürece katııır ve katılımcıları sınıflardaki değişime katkıda bulunmaya çalışır (Creswell, 2012).

Eylem araştırması türleri arasında işbirliğine dayalı eylem araştırması, uygulamanın geliştirilmesi için bir "ortak uzmanlık" kültürü (Mitchell, Reilly \& Logue, 2009) sağlar. Araştırmacılar ve öğretmenlerle işbirliği yapmak, öğretimin geliştirilmesi için teori ve pratik arasında köprü oluşturmada önemli bir role sahiptir. Bu araştırma türü aynı zamanda bir mesleki gelişim türüdür ve araştırmacılar ile öğretmenler arasındaki bağlantının niteliği sınıf öğretimi için anlamlı ve uygulanabilir olmasını amaçlamaktadır (Cochran-Smith, 1991; Mitchell, Reilly \& Logue, 2009). İ̧̧birlikçi eylem araştırması, öğretmenlerin yeni bir araştırma ortamı için ortak araştırmacı olarak farklı paydaşlarla işbirliği yapmalarını sağlar.

Araştırmacılar ile kurulan başarıı bir işbirliğine dayalı eylem araştırması ilişkisi (Kember et. al., 1997) öğretmenlerin sınıftaki pedagojik uygulamalarına rehber olabilmekte; mesleki gelişimleri ve öğrenmeleri için destek sağlayabilmektedir (Mitchell, Reilly \& Logue, 2009). Araştırmacı, öğretmenlerin uygulamalarını geliştirmek için sürece katıır ve katılımcıları sınıflardaki değişime katkıda bulunmaya çalışır (Creswell, 2012).

Çalışma Ankara'da bulunan bir anaokulunda gerçekleştirilmiştir. Bu çalışmanın motivasyonu, akademik yılın başındaki öğretmen eğitimi seminerinden sonra başlamıştır. Araştırmacı öğretmenlerle tanışmış ve bu eğitimler kapsamında ele alınacak konular hakkında toplantılar yapılmıştır. Toplantılarda, öğretmenlerin değerlendirme uygulamaları hakkında desteğe ihtiyaç duydukları kararına varılmıştır. Araştırmanın araştırma soruları, öğretmenlerle yapılan bu toplantılarda formüle edilmiştir. Bu çalışmada, erken çocukluk öğretmenlerinin biçimlendirici değerlendirme uygulamalarını değiştirmek ve ileriye dönük planlarını yönlendirmek için biçimlendirici değerlendirme kullanmalarını sağlamaktır. Çalışmadaki bir öğretmen eğitimcisi olarak araştırmacının rolü öğretmenlere biçimlendirici değerlendirme uygulamaları aracılığıyla danışmanlık yapmaktır. Sürecin başında katılımcı öğretmenler bilgilendirilmiş ve çalışmaya dair onayları alınmıştır. Çalışmanın katılımcılarını üç okul öncesi öğretmeni oluşturmuştur. Öğretmenlerden ikisi, öğretmenlik deneyimlerinin ilk yıllarını, diğer öğretmen ise ikinci yılını deneyimlediği sürede çalışma gerçekleşmiştir. Katıımcı öğretmenler üniversitelerin önlisans programlarından mezuniyet derecesine sahiptir. Öğretmenler değerlendirme için 
herhangi bir eğitim almadıklarını ve değerlendirme uygulamalarında kendilerini yetersiz bulduğunu belirtmişlerdir.

Öğretmenler sınıflarında ziyaret edilmiş, gözlemler yapılmış ve saha notları alınmıştır. Eğitim sonunda öğretmenlerle deneyimleri hakkında görüşmeler yapılmıştır. Veriler, yarı yapılandırılmış görüşmeler ve çalışmadaki her sınıfta yapılan gözlemlerle toplanmıştır. Her öğretmen haftada bir kez toplam 10 hafta ziyaret edilmiştir. Her saha ziyareti yaklaşık 50-60 dakika sürmüştür. Sürecin sonunda, her öğretmen ile biçimlendirici değerlendirme deneyimleri ile ilgili yarı yapılandırılmış görüşmeler yapılmıştır.

Çalışmanın veri analizi için, sürekli karşılaştırmalı veri analizi yöntemine dayanan endüktif bir yaklaşım izlenmiştir (Strauss \& Corbin, 1998). Veriler ilk aşamada yapısal kodlama ile kodlanmıştır. Bu süreçte, araştırmacı görüşme çözümlerini ve alan notlarını okuyarak ilk kodları analiz etmiştir. i̇kinci aşamada, elde edilen kodların birbirleriyle olan ilişkileri incelenmiş ve yeniden kodlanmış ve kategoriler eksenel kodlama ile oluşturulmuştur (Saldana, 2016). Analiz süreci, kodları daha kapsayıcı temalar altında birleştirerek sonlandırılmıştır.

Araştırmacı tarafından araştırmanın güvenilirliğini ve güvenilirliğini sağlamak için bazı stratejiler kullanılmıştır. Üçgenleme, sonuç çıkarmak için kullanılan çok temel veri kaynakları arasındaki stratejilerden biridir. Çalışmanın güvenilirliği için aynı zamanda uzun süreli katılım ve kalıcı gözlem kullanılmıştır (Lincoln \& Guba, 1985). Verilerin toplanması, katılımcıların uygulamalarının anlaşılması ve araştırmanın derinliği için sürekli gözlem yapılması için yeterli zaman harcanmıştır. Çalışma aynı zamanda katılımcıların çalışmanın güvenilirliğine ilişkin stratejilerinin ve zengin alıntılarını detaylı bir şekilde sunmaktadır (Merriam, 1998).

Eylem araştırması, planlama, uygulama ve gözlemleme, yansıtma ve tekrar karar almayı içeren bir yansıtıcı döngüye sahiptir (Kemmis \& McTaggart, 2000). Şekil 1, bu çalışmanın yansıtıcı döngüsünü göstermektedir.

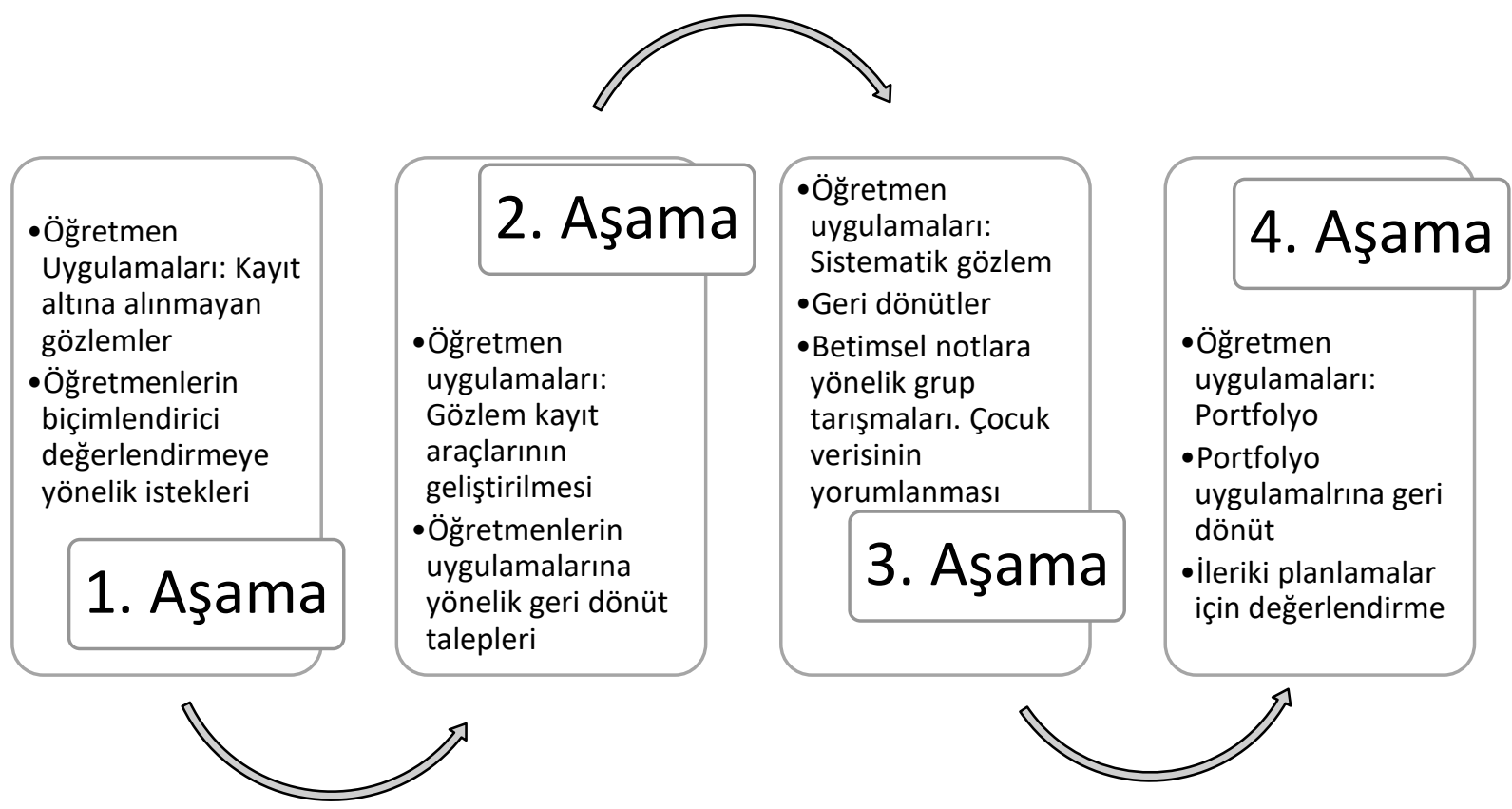

Şekil 1. İşbirlikçi eylem araştırmasının yansıtıcı döngüsü.

1. Aşama: Çalışmanın ilk aşamasında öğretmenlere gözlem, gözlem araçları, çocuklardan veri toplama, verilerin yorumlanması ve paydaşlarla paylaşılması, ileri öğretim için kararların alınması süreçlerini içeren biçimlendirici değerlendirme konusunda eğitimler verilmiştir. Bu eğitimden sonra üç sınıfta gözlemler yapılmış ve değerlendirme uygulamaları hakkında saha notları alınmıştır. Öğretmenlerin tümü, öğrenme için değerlendirmenin rolünün farkında olduklarını ancak sınıflarında uygulamada zorluk çektiklerini belirtmiştir. Öğretmenlerin sadece sistematik olmayan gözlem yaptıkları ilk gözlem notları arasında yer almıştır. 
Öğretmenler, değerlendirme araçları hakkında yeni bir eğitim talebinde bulunmuş ve deneyimlerini tartışmak üzere yeni toplantı kararı alınmıştır.

2. Aşama: Öğretmenlerle birlikte değerlendirme uygulamalarıyla ilgili bir toplantı gerçekleşmiştir. Öğretmenler, sistematik gözlem yapma ve çocuklardan veri toplama süreçlerinde yaşadıkları zorlukları dile getirmiştir. Kendilerine sunulan somut gözlem araçları örnekleriyle tartışmalar yapılmışır. Elde edilen verilerin değerlendirme araçları aracılı̆̆ıla planlama ve öğretme üzerindeki rolü hakkında konuşulmuştur. Bu aşama öğretmenlerin kendi gözlem kayıt araçlarını hazırlama ve bunları sınıflarında kullanma kararıyla sona ermiştir.

3. Aşama: Öğretmenler sistematik gözlem yapmaya başlamışlardır. Yapılan gözlemlerde masalarında ve / veya klasörlerinde farkıı veri toplama araçları kullandıkları görülmüştür. Kendi araçları için geri bildirim istemişler, her deneyimlerinde mini toplantılar gerçekleştirilmiştir. Gözlemlerini anekdot kayıtlar ile kayıt altına aldıklarını belirtmişlerdir. Öğretmenler, gözlem verilerini çocukların öğrenmeleri ve gelişmeleri hakkındaki kararlarında kullandıklarını ifade etmiştir. Öğretmenler kayıtlarını bir portfolyo (gelişim dosyası) eşliğinde dokümante etmeye başlamıştır.

4. Aşama: Öğretmenler, bireysel çocuk portfolyolarını, çocukların kendi portfolyo karar alma süreçlerine dahil edilmesiyle organize etmişlerdir. Öğretmenler daha sonraki planları için değerlendirme verilerini kullanmaya başlamışlardır.

\section{Bulgular}

\section{Biçimlendirici değerlendirme için sistematik gözlem ve dokümantasyonun önemi}

Sürecin başlangııında gerçekleştirilen toplantılarda, etkili bir biçimlendirici değerlendirme için gözlem uygulamalarının iyileştirilmesi gerektiğinin farkına varılmıştır. Illk gözlemlerde, öğretmenlerin tek değerlendirme uygulamasının fotoğraf çekmek olduğu görülmüştür. Öğretmenlerin fotoğrafları ailelere göndermek üzere çektikleri ve değerlendirme amaçı kullanmadıkları tespit edilmiştir. Herhangi bir betimsel kayıt almadıkları veya gözlemlerini kayıt altına almadıkları gözlemlenmiştir. Ayrıca çocukların gelişimini ve öğrenmesini izlemek için herhangi bir değerlendirme aracı kullanmadıkları not edilmiştir. Öğretmenler, sınıf uygulamalarını tartıştığımız değerlendirme araçlarıyla ilgili bir toplantı talebinde bulunmuştur. Her öğretmene gözlem süreçleri sorulmuş ve gözlemlerinin nasıl kaydedileceğine dair somut örnekler sunulmuştur. Katılımcı öğretmenlere kontrol listeleri, değerlendirme listeleri, anekdot kayıtları gibi çeşitli kayıt gözlemleri için örnekler gösterilmiştir. Öğretmenler, örnekleri gördükten sonra kendilerini daha güvende hissettiklerini ifade etmiştir. Elde edilen verilerin değerlendirme araçları aracılığıyla planlama ve öğretme üzerindeki rolü tartışımış ve bu araçları içeren planların sıradan planlarından farklı olacağı, çünkü çocukların gelişimi ve öğrenmeleri için onlara yol gösterici olacağı öğretmenler tarafından belirtilmiştir. Bu aşama öğretmenlerin kendi değerlendirme araçlarını hazırlama ve bunları sınıflarında kullanma kararıyla sona ermiştir. Öğretmenler değerlendirme araçları geliştirmeye başlamıştır. Sınıflarında yapılan gözlemlerde sınıf tablolarında veya klasörlerinde farklı veri toplama araçları görülmüştür. Öğretmenlerin gelişimsel kontrol listeleri geliştirdikleri, gözlem notları aldıkları ve çocukların öğrenme anlarını yansıtan fotoğraflarııı çektikleri gözlemlenmiştir.

Araştırmanın verileri öğretmenlerin gözlemler sırasında daha sistematik olduklarını ortaya koymuştur. Saha ziyaretlerinin ilk haftalarında, öğretmenlerin yalnızca sistematik olmayan yani informal gözlemler yaptıkları not edilmiştir. Ancak, eğitimler devam ettikçe, sistematik gözlem ve gözlem toplama araçları uygulamalarının geliştirildiği gözlemlenmiştir. Öğretmen 1, biçimlendirici değerlendirmenin daha sistematik olmasına rehberlik ettiğini ve gözlem uygulamalarını desteklediğini belirtmiştir. Kullandı̆̆ı değerlendirme araçları arasında anekdot kayıtların ve anlatı notlarının onun için çok faydalı olduğunu ifade etmiştir. Betimsel değerlendirme araçlarının, her çocuğun ve aynı zamanda sınıftaki tüm çocukların gelişiminden haberdar olmaları bakımından değerli olduğunu belirtmiştir. Onun sözleriyle: "Çocukların öğrenmesini yansıtan bazı şeyler (kanıtlar) yazdım ve kendi gelişimimiz için de faydalı olduğunu gördüm. Örneğin, A.'nın (çocuğun adı) göstergelerini kaydederken, adım adım gerçekleşen bir ilerleme yaşadık. A.'nın gelişsim ve öğrenme kanıtlarını sistematik olarak kaydediyordum ve ardından gelişimine destek olmak için öğretim stratejilerimi ya da materyallerimi değiştiriyorum ya da revize ediyorum. Ama sonra, bu ilerlemenin sınıftaki diğer bazı çocuklarda görülmediğini fark ettim. Bu çocuklar, daha az anektod kayıtlar yazdığım çocuklardı."

Öğretmen 2 gözlem olmadan plan yapmanın mümkün olmadığını söylemiştir. Dönem başında herhangi bir gözlem notu almadığını ve hatırladıklarına dayanarak çocukların gelişim ve öğrenmelerini değerlendirdiğini 
belirtmiştir. "Bu uygulamalardan sonra daha sistematik olduğumu, not almam gerektiğini ve sınıfta gözlemlediklerimi kaydetmem gerektiğini öğrendim."

Öğretmen 3'ün ifadeleri de, gözlem sürecinin öğretme ve öğrenmeye katkııının önemine dair farkındalığının arttığııı göstermektedir. "Gözlem, çocukları gözlerinde ışı̆̆a tanımakla ilgilidir. Gözlem, tüm süreci sınıfta ve öğretmenlerin uygulamalarında görselleştirmemizi sağlar. Her şeyi (bir sınıfta deneyimlenen) görünür ve net yapan bir sistemdir." Öğretmen, sürecin başında çocuklarla etkinlik yaparken gözlem notları almakta zorluk çektiğini belirtmiştir. Eylem araştırması aşamaları kendi öğrenme sürecine yansımış ve biçimlendirici değerlendirme uygulayarak becerilerini nasıl geliştirebileceğini tanımladığı görülmüştür. Onun sözleriyle, "Artık çocukların öğrenmesinin kanıtlarını kaydetmenin etkili olduğunu biliyorum, belirli bir öğrenme hedefini gösteren bir çocuğu yakaladığımda not almak önemli."

\section{Ileriki planlamalara çocuk katııımını esas alan biçimlendirici değerlendirme ile yön vermenin önemi}

Katıııcı öğretmenler, biçimlendirici değerlendirmenin çocukların dinlenerek ve çocukların ihtiyaçlarına cevap vermek için bir araç olmasını bekleyerek bu sürece başlamışlardır. Başlangıçtaki gözlemler sırasında, öğretmenlerin uygulamalarının müfredata gömülü değerlendirme uygulamalarından oldukça uzak olduğu fark edilmiştir. Öğretmenlerin sadece öğrenmelerini değerlendirmek için etkinliklerin sonunda çocuklara soru sordukları gözlemlenmiştir. Planlama ve yansıtma toplantılarımızda öğretmenler, biçimlendirici değerlendirmeyi bütünleştirmek için sınıf deneyimlerini yeniden kurmaları gerektiğine karar vermiştir. Öğretmen merkezli etkinliklerin öğretmenlerin biçimlendirici değerlendirme yapmasına izin vermediği fark edilmiştir. Öğretmenler çocuklar için daha az yapılandırıımış etkinlikler tasarlamış ve sınıf etkinlikleri sırasında "öğretim görevlisi" yerine "rehber" olmaya çalışmışlardır. Bu çocuk merkezli yaklaşım öğretmenlerin çocukları dinlemelerine ve çocuklarının sesini kararlarında dikkate almalarına olanak sağlamıştır. Öğretmen 3 sınıfta çocuklarla ilgili bakış açııını vurgulamıştır ve çocukları müfredatın merkezine aldığııı ve önceki faaliyetlere yansıdığıı vurgulamıştır. "Önceden belirlenmiş bir sürede tamamlanması gereken bir faaliyete karar verdiğimi ve çocukları çalışmalarını tamamlamaya zorladığımı, sonra kendime durmam, çocukları dinlemem ve ne yapmak istediklerini düşünmem gerektiğini fark ettim".

Katılımcı öğretmenler biçimlendirici değerlendirme uygulamalarının çocuğu merkeze alması ile öğretmen rolünü de değiştirdiğini ifade etmiştir. Öğretmen 3, "Çocukların ihtiyaçlarını daha fazla düşüneceğim, bu süreçten sonra onların ihtiyaçlarına daha fazla önem vermek istiyorum" demiştir. Ayrıca, çeşitli değerlendirme araçlarıyla çocuklardan veri topladıktan sonra öğretmenlerin çocukların gelişimi ve öğrenmesine ilişkin yorumlarının değerini vurgulamıştır. Onun sözleriyle, "Çocukların gelişimini ve öğrenmesini değerlendirmek önemlidir, ancak durum sadece böyle değil. Değerlendirmelerimize bağlı olarak onlara katkıda bulunmalıyız (çocukların gelişimi ve öğrenmesi)."

Katılımcı öğretmenlerle yapılan gözlemler ve görüşmeler öğretmenlerin ileri planlama için değerlendirmenin önemini kabul ettiğini göstermiştir. Gözlemler, öğretmenlerin değerlendirme verilerini ders planları için kullandıkları ortaya çıkmışır. Öğretmenler gözlem notlarına atıfta bulunurken ve bu notlara dayanarak etkileri konusunda kararlar alırken gözlemlenmiştir. Öğretmen $1^{\prime}$ in biçimlendirici değerlendirmenin değeri perspektifinden ortaya çıkan önemli bir konu, öğretim planlarına rehberlik etmesi olmuştur. Öğretmen 1 , biçimlendirici değerlendirme uygulamalarının, sınıf deneyimlerinin bir sonraki aşamada nereye gitmesi gerektiğine karar vermesine yardımcı olduğunu şu şekilde belirtmiştir: "Planlarımı çocukların ihtiyaçları ve ilgi alanlarına göre yapacağım, daha sistematik olacağım." Ayrıca, çocukların gelişimine bakmanın önemini vurgulamışır. Ayrıca, çoklu değerlendirme araçlarını inceleyerek çocukların öğrenmelerini geliştirmenin yollarını yansıtabildiğini belirtmiştir.

Öğretmen 2, biçimlendirici değerlendirme verilerinin onlara çocukların öğrenmesi ve gelişimi hakkında bilgi sağladığını ifade etmiştir. Biçimlendirici değerlendirmenin öğretim sürecinin bir parçası olduğunu belirtmiştir. Öğretim sürecinin her çocuğun ihtiyaçlarını karşılamasını gerektiğine inandığını belirterek, planlarını yapmada önceki uygulamalarını karşılaştırmış ve şu ifadeleri iletmiştir: "Hazır etkinlikler arıyordum ve bunları sınıfta uyguluyordum ve çocukların birçoğu aktivitelerden memnunsa ben de mutlu oluyordum ama şimdi biliyorum $k i$ daha fazla çocuk merkezli olmalıyım."

Öğretmenlerin, çocukların öğrenme deneyimlerini yönlendirmek için değerlendirme yapmanın önemine dair artan farkındalıkları edinilen bir diğer bulgudur. Örneğin, Öğretmen 1, dönemin başında sadece sınıf etkinlikleriyle ilgili sorularına çocukların cevaplarını not ettiğini belirtmiştir. "Etkileşim sırasında veya bir faaliyet 
üzerinde çalısırken sorularıma cevaplarının yanı sıra ifadelerini, alıntılarını da not etmem gerektiğini anladım" diyerek öz-değerlendirme yapmıştır.

Gözlemler ve görüşmeler biçimlendirici değerlendirme uygulamalarının öğretmenlerin öğretmenlik uygulamalarını geliştirmelerini sağladığını göstermiştir. Öğretmenlerin biçimlendirici değerlendirmenin değeri hakkında yorumda bulundukları önemli bir konu, öğretimlerini değiştirmesi ve geliştirmesi gerektiği ile ilgilidir. Örneğin, Öğretmen 3 deneyimlerine yönelik yansıtmalarda bulunmuş ve "gözlem notları aldıktan sonra ne yapacağımı düşünüyorum. Özellikle, sınıfta olumsuz bir yön gördüğümde uygulamalarımı geliştirme yollarına karar vermeye başladım." demiştir. Öğretmen 2 ayrıca biçimlendirici değerlendirmenin daha kanıta dayalı bir şekilde hareket etmesini sağladığına dikkat çekerek "Süreci kanıta dayalı olduğu için seviyorum, kanıt göstermemize izin veriyor (çocukların gelişimi ve öğrenmesi)" demiştir.

\section{Biçimlendirici değerlendirme uygulamaları için tamamlayıcı ve yansıtıcı bir araç olarak portfolyo}

Sürecin ilk aşamalarında katılımcı öğretmenlerin portfolyo uygulamalarının çocukların ürünleri ile sınırlı olduğu gözlemlenmiştir. İşbirlikçi eylem araştırması ekibinin tüm üyeleri, portfolyonun biçimlendirici değerlendirme için güçlü bir dokümantasyon aracı olduğuna ve katıımcı öğretmenlerin mevcut portfolyolarının geliştirilmesi gerektiğine karar vermiş̧ir. Mevcut portfolyolar, çocukların gelişimi ve öğreniminin bütünsel bir resmini sunmaktan uzak olarak tanımlanmıştır. Biçimlendirici değerlendirmenin uygulanmasıyla birlikte, portfolyonun bir dokümantasyon aracı ve yansıtıcı uygulama olarak yeniden yapılandırılması gerektiğinin farkına varıımıştır. Yapılan toplantılarda, çocuklarla, velilerle ve öğretmenlerle paylaşılacak sistematik gözlemler sırasında toplanan verilerle Portfolyo düzenleme konusunda uzun süreler harcanmışıı. Öğretmenlere, küçük çocukların öğrenme ve gelişmelerini değerlendirmek için betimsel kayıtlar, gözlem notları, kontrol listeleri, değerlendirme listeleri, çocukların fotoğraflarını ve çocukların portfolyoları gibi çoklu araçlar ve yöntemler kullanmaları önerilmiştir. Öğretmenler sistematik olarak çocukların bireysel portfolyolarında çocukların gelişimine ve öğrenmelerine dair kanıtlar toplamıştır. Çocuk portfolyoları, sistematik sınıf gözlemleri sırasında topladıkları birçok gözlem kayıt araçları içermektedir. Her çocuğun portfolyosu, her gelişim alanı için birden fazla kanıt içermeye başlamıştır. Öğretmenler betimsel kayıtlarını, öğrenme deneyimlerinin fotoğraflarını, kontrol listelerini, gözlem notlarını ve çocuk eserleri ile ürünlerini portfolyolarında toplamıştır. Öğretmenler, bireysel çocuk portfolyolarını, çocukları kendi portfolyolarının karar alma süreçlerine katıımıyla organize etmişlerdir. Öğretmenlerin portfolyo içerikleri için geri bildirimde bulunulmuş ve öğretmenler çocukların öğrenmesi ve sınıf uygulamaları ile ilgili değerlendirmelerde bulunmuştur.

Öğretmenler özellikle portfolyoları örneklemişler ve bütünsel bir portfolyonun öğretim süreçlerinde ayarlamalar için karar vermelerine nasıl yardımcı olduğunu dile getirmiştir. Öğretmen 2, "Gelişimin bütünsel görüşünü ele almak için ne yapmam gerektiğini anladım. Portfolyoya baktım ve müfredatta cevapsız bir şey olup olmadığını veya dikkat edilmesi gereken konulara karar verilip verilmediğini gördüm" demiştir. Ayrıca, bu öğretmen çocuk portfolyolarına bakarak çocukların en çok erken okuryazarlık ile ilgili çalışmalarına portfolyolarında yer vermek istediklerini görmüş ve bu yönünün güçlü olduğunu görmesine olanak sağladığını dile getirmiştir.

Katılımcı öğretmenler ayrıca portfolyoyu, çocuklarının faaliyetlerinin karar verme süreçlerine dahil edilmesi konusundaki uygulamaları konusundaki katkıları hakkında yorum yapmışlardır. Öğretmenlere portfolyo uygulamalarında, çocuklara da söz hakkı vermeleri, çocukları karar verme süreçlerine dahil etmeleri önerilmiştir. Sınıflarda yapılan gözlemler sırasında öğretmenlerin portfolyo süreçlerine çocukları dahil ederek, çocuklara tekrar öğrenmeleri ve öğrenmeleri hakkında düşünmeleri için fırsatlar sağladığı görülmüştür. Öğretmen 2, çocukları değerlendirme sürecine davet etmenin öğrendiklerini görmesini sağladığını belirtmiştir. Çocukların yaptığı öz-değerlendirmelerin, önceki öğrenme deneyimlerini arttırma açııından değerli olduğu öğretmenler tarafından vurgulanmıştır.

\section{Tartışma, Sonuç ve Öneriler}

Araştırmaya katılan öğretmenler, biçimlendirici değerlendirmeyi, eğitim planları için bir rehber olarak tanımlamışır. Torrance ve Pryor (2001) 'in bulgularına paralel olarak, bu çalışma biçimlendirici değerlendirmenin öğretmenlerin öğretmenlik uygulamalarını geliştirmelerini sağladığını göstermiştir. Biçimlendirici değerlendirmenin uygulama aşamaları başlangıçta öğretmenlerin mevcut uygulamaları hakkında kişisel farkındalıklarının ortaya çıkması ile sonuçlanmışır. Torrance'e (2001) göre, pedagojik öz-farkındalık, etkili biçimlendirici değerlendirme deneyimleri için önemli bir noktadır. Öğretmenler işbirliğine dayalı bir eylem araştırması döneminde biçimlendirici değerlendirme yaşadıkça, var olan uygulamalarını tanımış ve onlara 
yansıtmalarda bulunmuştur. Daha sonra, biçimlendirici değerlendirmenin sınıftaki öğrenme ve öğretim süreçlerini desteklemede potansiyel olarak daha etkili olduğunu kabul etmeye başlamıştır (Black \& Wiliam, 2009; Shepard, 2000). Bu çalışma, biçimlendirici değerlendirmenin öğrenme değerlendirmesi için çok önemli bir yol olduğunu vurgulamıştır. Öğretmenlerin kararlarını öğretim planlarında düzenlemelerine yardımcı olmuştur. Öğretmenler biçimlendirici değerlendirmenin çocukların ihtiyaçlarını belirlemede ve öğretimlerini buna göre düzenlemede etkili olduğunu vurgulamıştır. Öğretmenler, farklı deneyimlerin çocukların öğrenmesinin ilerlemesi üzerindeki etkilerini görebilme fırsatı bulmuştur. Buldu'nun (2010) bulguları ile benzer olarak, biçimlendirici değerlendirme öğretmenleri çocukların öğrenme deneyimleri ve çocuklardan toplanan verilerin sistematik bir şekilde toplanması konusunda öğretim amacıyla kullanılacak bir araç olarak bilgilendirmiştir. Öğretim stratejilerini ve pedagojik karar vermeyi çocukların ihtiyaçlarına ve ilgi alanlarına uyarlamak, kapsamlı bir bilgi ve beceri tabanı gerektirir. Ayrıca, amaçlı öğretime ilişkin araştırmalar, amaçlı öğretimin olumlu öğretmen-çocuk ilişkisi üzerindeki etkisini vurgulamaktadır (McLaughlin, Aspden \& Snyden, 2016).

Araştırmanın bulguları, biçimlendirici değerlendirme uygulamasının öğretmenlerin çocukları dinlemesini sağladığını da ortaya koymuştur. Sak, Tantekin-Erden ve Morrison (2018) tarafından yapılan çalışmada, öğretmenlerin değerlendirme uygulamalarının çocuk merkezli olma açısından yeterli olmadığı tespit edilmiştir. Bu çalışma, işbirlikçi eylem araştırmasının öğretmenlerin çocuk merkezli değerlendirme uygulamalarını geliştirmek için değerli bir araç olabileceğini göstermektedir. Bu araştırmanın öğretmen katılımcıları, çocukları dinlemeye ve daha fazla duymaya ve kendi öğrenmelerini değerlendirme fırsatı verdiklerini ifade etmişlerdir. Black ve Wiliam (2009), biçimlendirici değerlendirme uygulamalarının güçlü bir yönü olarak çocukları kendi öğrenimlerinin sahipleri olarak harekete geçirmeyi vurgulamıştır.

Çalışmanın bir diğer önemli bulgusu, her bir sınıftaki portfolyo uygulamalarının dönüşümüne yöneliktir. Bütüncül bir portfolyonun, çocukların dinlenmesi için güçlü bir platform sağladığı görülmüştür. Öğretmenlerin yeni portfolyo uygulamaları, çocukları sürece davet etmiş ve çoklu araçlarla portfolyoları, çocukların önceki öğrenme deneyimlerini hatırlamalarına ve ziyaret etmelerine yardımcı olmuştur. Portfolyolar ayrıca öğretmenlere her çocuğun öğrenmesini, gelişmesini ve sonuçları analiz etmesini sistematik olarak belgeleme fırsatı sağlamıştır. Bu bağlamda, bu araştırma öğretmenlere çocukların sınıf deneyimlerini zenginleştirmek ve öğretmen uygulamalarını desteklemek için portfolyo kullanmalarını önermektedir (Laski, 2013; Seitz, 2008). Portfolyo, bir çocuğun belli bir süre içinde ilerlemesini destekleyen bir arşiv niteliği taşır, çocukların geçmiş deneyimlerini destekler, öğretmenlerin değerlendirme uygulamalarını destekler ve ailelerle iletişim için etkili bir araçtır.

$\mathrm{Bu}$ çalışmadaki süreç, öğretmenlerin uygulamalarını profesyonel bir bakış ile görmelerini, çocukların gelişimini ve öğrenmelerini değerlendirmelerini ve bu konuda literatürde vurgulandığı gibi müfredatın uygulanmasına yön vermelerini sağlamıştır (Morrison, 2012). Bu çalışmada yer alan öğretmenler, sistematik gözlemin sınıf deneyimleri üzerindeki rolünü de yorumlamıştır. Sistematik ve amaçlı bir gözlem, öğretmenler tarafından kullanılacak olan müfredat planlama ve öğretim stratejileri için yardımcı olacaktır (McAfee \& Leong, 2011). Erken dönem çocukluk öğretmenleri ile değerlendirme uygulamaları üzerine yapılan araştırmalar, öğretmenlerin çoğunlukla çocukların değerlendirilmesinde gözlemden faydalandığını ortaya koymaktadır (Hanes, 2009; Koçak, 2005; Schappe, 2005; Sezer, 2010). Öğretmenlerin gözlem uygulamaları, çocuğu bir bütün olarak görmek ve aynı anda birçok bileşeni görmek için değerli bir araçtır (Schappe, 2005). Biçimlendirici bir değerlendirme aracı olarak pedagojik dokümantasyon üzerine yapılan çalışmalar (Buldu, 2010; MacDonald, 2007) ayrıca gözlem ve dokümantasyon sürecinin öğretmenlerin öğretim kararları üzerindeki önemli rolünü ortaya koymuştur. Bu çalışmanın bulguları, biçimlendirici değerlendirme uygulamalarının yalnızca çocukların öğrenmelerini izlemelerini değil, aynı zamanda kendi eğitsel uygulamalarını da değerlendirmelerini sağladığını göstermiştir. Biçimlendirici değerlendirmenin uygulamalarının farkında olma rolünü vurgulamışlar ve öğretiminde ayarlamalar yapılıp yapılmayacağına karar vermeleri için onlara rehberlik ettiğini dile getirmişlerdir. Öğretim uygulamalarını incelemek ve geliştirmek için biçimlendirici değerlendirme uygulamalarının kullanılması alanyazında vurgulanan önemli unsurlardan birisidir (Shepard, 2009).

Bu çalışma, erken çocukluk ortamlarında biçimlendirici değerlendirme uygulamalarının geliştirilmesi ve araştırmacılar ile öğretmenler arasındaki işbirliğinin önemi açısından literatüre katkı sağlamayı amaçlamaktadır. Oldukça sınırlı sayıda araştırılmış bir konu olan biçimlendirici değerlendirme, öğretmenler tarafından uygulanması zor olarak karşılanmaktadır ve öğretmenler bu süreçleri karmaşık olarak tanımlamaktadır. Ancak, bu çalışma kapsamında, profesyonel bir işbirliği ile öğretmenlerin bu değerlendirme sürecini sınıflarında 
uygulayabildikleri ve değerlendirme planlarını yeni planların ayarlanması için yorumlayabildikleri gösterilmektedir.

Alan yazında yer alan araştırmalar, öğretmenlerin biçimlendirici değerlendirmeye yönelik bilgilerine odaklanmakta ve öğretmenlerin biçimlendirici değerlendirme uygulamalarını geliştirmeleri için mesleki gelişim etkinliklerini önermektedir (Black \& Wiliam, 2009; Shepard, 2000). Bu çalışmada, öğretmenlerin uygulamalarını geliştirmek için aynı zamanda bir mesleki gelişim modeli olan işbirlikçi eylem araştırması kullanılmıştır ve bulgular katılımcı öğretmenlerin biçimlendirici değerlendirme uygulamalarındaki ilerlemeleri göstermektedir. Araştırmalar, biçimlendirici değerlendirme uygulamalarının öğretmenleri zorladığını ve öğretmenler tarafından sıklıkla kullanılmadığını göstermiştir (Aydın, 2005; Çakan, 2004; Pilten, 2001; Shepard, 2000). Bu çalışma, öğretmenlerin sınıflarında biçimlendirme değerlendirme uygulamalarını eylem araştırması sürecinde uygulayabildiklerini ortaya koymuştur. Bu durumda, öğretmenlere destek verildiğinde, yalnızca değerlendirme açısından kendilerini geliştirmekle kalmamakta, aynı zamanda tüm uygulamalarını desteklemektedir. Öğretmenler, sınıflarında biçimlendirici değerlendirme uygulamak için profesyonel yardıma ve bilgiye ihtiyaç duyabilmektedir (Bennett, 2011). Araştırmacılar ve öğretmenler arasındaki işbirliği, öğretmenlerin uygulamalarını etkileme konusunda güçlü bir potansiyele sahiptir ve elde edilen başarının artmasıyla sonuçlanma potansiyeli yüksektir (Tayler, 2012). Bu çalışma ile eylem araştırmasının öğretmenlerin yaklaşımlarını değiştirmedeki dönüştürücü gücü vurgulanmaktadır. Öğretmenlerle yapılan eylem araştırması çalışmaları, eylem araştırmasının öğretmenlerin sınıf uygulamalarıyla ilgili gelişimindeki kritik katkısına da dikkat çekilmiştir (Pine, 2009).

Değerlendirme, özellikle erken yıllarda, öğretme ve öğrenmede kritik bir role sahiptir. Küçük çocukların gelişim ve öğrenme süreci karmaşıktır ve özetleyici ve geleneksel yöntemlerle değerlendirilmesi oldukça zordur. Öğretmenlerin küçük çocuklarla çalışırken daha fazla öğretim sürecine gömülü stratejilere ihtiyacı vardır. Sistematik gözlem, dokümantasyon, toplanan verilerin yorumlanması ve değerlendirme verilerinin daha sonraki planlama için kullanılması, biçimlendirici değerlendirmenin temel özellikleridir. Öğretmenlerin değerlendirme uygulamalarını iyileştirmeleri gerektiği araştırmalarla ortaya konulmuştur. Bu çalışma sayesinde işbirlikçi eylem araştırması, öğretmenlerin biçimlendirici değerlendirme konusundaki profesyonel öğrenmelerini desteklemek için bir yöntem olarak önerilmektedir. Öğretmenler, erken yaşlarda öğrenmenin değerlendirmesi yerine öğrenme için değerlendirmeyi kullanmaya davet edilmektedir. Erken çocukluk öğretmenleri için bütünsel bir çocuk portfolyosu uygulanması da önerilmektedir. Portfolyolar çocukların gelişimini izlemek, program uygulamalarını değerlendirmek ve ebeveynleri çocukların gelişimi ve öğrenmesi hakkında bilgilendirmek için değerli bir araçtır.

$\mathrm{Bu}$ araştırmanın kapsamı, biçimlendirici değerlendirmenin çocukların gelişimi ve öğrenmesi üzerindeki rolünü incelemeden öğretmen uygulamaları ve biçimlendirici değerlendirmeye ilişkin algılarla sınırlıdır. Bu araştırmada, sürecin çocuklar tarafından nasıl sonuçlandığı incelenmemiştir. Biçimlendirici değerlendirme uygulamalarının, erken yıllardaki gelişim ve öğrenmedeki etkilerini araştırmak oldukça önemlidir.

Araştırma, mesleki gelişim tasarımlarının öğrenme değerlendirmesinde rol oynadığına dikkat çekmektedir. Öğretmenlerin mesleki uygulamalarını değerlendirme uygulamalarında araştırmak ve ihtiyaçlarını karşılamak ve uygulamalarına katkıda bulunmak için mesleki gelişim modelleri geliştirmek gerekir. Daha fazla öğretmenle çalışmak ve biçimlendirici değerlendirme konusundaki uygulamalarını geliştirmek için boylamsal araştırmalara ihtiyaç vardır. Özellikle ulusal bağlamda, erken çocukluk öğretmenlerinin biçimlendirici değerlendirme uygulamalarını araştırmak ve mesleki ihtiyaçlarına cevap vermek ve sınıf uygulamaları için gerekli yardımı sağlamak için biçimlendirici değerlendirmenin önemini arttırmaya hizmet edecek çalışmalara ihtiyaç vardır. 


\section{References}

Beaty, J. J. (2012). Observing development of the young child. Upper Saddle River, NJ: Merrill/Prentice Hall.

Bennett, R. E. (2011). Formative assessment: A critical review. Assessment in Education: Principles, Policy \& Practice, 18(1), 5-25.

Black, P. (2001). Dreams, strategies and systems: Portraits of assessment, past, present and future. Assessment in Education: Principles, Policy \& Practice, 8(1), 65-85.

Black, P., Harrison, C. Lee, B. Marshall, \& D. Wiliam (2004). Working inside the black box: Assessment for learning in the classroom. The Phi Delta Kappan, 86(1), 8-21.

Black, P. \& Wiliam, D. (1998). Assessment and classroom learning. Assessment in Education: Principles, Policy and Practice, 5(1), 7-73

Black, P. \& Wiliam, D. (2009). Developing the theory of formative assessment. Educational Assessment, Evaluation and Accountability, 21, 5-31.

Bowman, B. T., Donovan, M. S., \& Burns, M. S. (2000). Eager to learn: Educating our preschoolers. Washington DC: National Academies Press.

Buldu, M. (2010). Making learning visible in kindergarten classrooms: Pedagogical documentation as a formative assessment technique. Teaching and Teacher Education, 26, 1439-1449.

Carr, M. (2001). Assessment in early childhood settings: Learning stories. London: Paul Chapman

Cochran-Smith, M. (1991). Reinventing student teaching. Journal of Teacher Education, 42, 104-118.

Crepps, S. (1999). Reading, writing, and mathematics in a fifth grade class. In Windows on our classrooms. Davis: University of California

Creswell, J. W. (2012). Educational research: Planning, conducting, and evaluating quantitative and qualitative research. Boston: Pearson Education, Inc.

Çakan, M. (2004). Öğretmenlerin ölçme-değerlendirme uygulamaları ve yeterlik düzeyleri: ilk ve ortaöğretim. Ankara Üniversitesi Eğitim Bilimleri Fakültesi Dergisi, 37(2), 99-114.

Darling-Hammond, L., Wei, R. C., Andree, A., Richardson, N., \& Orphanos, S. (2009). Professional learning in the learning profession. Washington, DC: National Staff Development Council.

Dixon, H. (1999). The effects of policy and practice: An analysis of teachers' perception of school based assessment practice. Unpublished MedAdmin thesis, Massey University, Palmerston North, New Zealand.

Donovan, M.S., Bransford, J.D. \& Pellegrino, J.W. (Eds.), (2000). How people learn: Bridging research and practice. Washington, DC: National Academy Press.

Dunn, K. E., \& Mulvenon, S. W. (2009). A Critical Review of Research on Formative Assessment: The Limited Scientific Evidence of the Impact of Formative Assessment in Education. Practical Assessment, Research \& Evaluation, 14(7). Retrieved April, 20, 2019, from: http://pareonline.net/getvn.asp?v=14\&n=7

Gullo, D. F., \& Ambrose, R. P. (1987). Perceived competence social acceptance in kindergarten: Its relationship to academic performance. Journal of Educational Research, 8(1), 38-32.

Hanes, B. M. (2009). Perceptions of early childhood assessment among early childhood educators (Doctoral dissertation). Retrieved from: http://viu.summon.serialssolutions.com/link/0/

Hattie, J. \& Timperley, H. (2007). The power of feedback. Review of Educational Research, 77(1), 81-112. doi:10.3102/003465430298487

Heritage, M., Kim, J., Vendlinski, T., \& Herman, J. L. (2009). From evidence to action: A seamless process in formative assessment?, Educational Measurement: Issues and Practice, 28(3), 24-31.

Herr, J. (2012). Working with young children. Tinley Park, IL: The Goodheart Willcox Company.

James, M. \& Pedder, D. (2006). Professional learning as a condition for assessment for learning. In J. Gardner (Ed.), Assessment and learning (pp. 27-45). London: Sage. 
Kember, D., Tak-Shing, H., Bick-Har, L., Lee, A., Ng, S., Yan, L., et al. (1997). The diverse role of the critical friend in supporting educational action research projects. Educational Action Research, 5, 463-481.

Kemmis, S., \& McTaggart, R. (2000). Participatory action research. In N. Denzin \& Y. Lincoln (Eds.), Handbook of qualitative research ( $2^{\text {nd }}$ ed., pp. 567-605). Thousand Oaks, CA: Sage Publications.

Koçak, N. (2005). Bireyi tanıma tekniklerinin okul öncesi eğitim kurumlarinda uygulanmasina ilişkin öğretmen görüslerinin incelenmesi. Unpublished Master Thesis, Selçuk University, Turkey.

Laski, E. V. (2013). Portfolio picks: An approach for developing children's metacognition. YC Young Children, 68(3), 38.

Lincoln, Y. S., \& Guba, E. G. (1985). Establishing trustworthiness. Naturalistic Inquiry, 289, 331.

MacDonald, M. (2007). Toward formative assessment: The use of pedagogical documentation in early elementary classrooms. Early Childhood Research Quarterly, 22(2), 232-242.

McAfee, O. \& Leong, D. J. (2011). Assessing and guiding young children's growth and development (6 ${ }^{\text {th }}$ ed.). Needham Heights, MA: Allyn \& Bacon.

McLaughlin, T., Aspden. K., \& Snyder, P. (2016). Intentional teaching as a pathway to equity in early childhood education: Participation, quality, and equity. New Zealand Journal of Educational Studies, 51, 175-195.

McMillan, J. H., Venable, J. C., \& Varier, D. (2013). Studies of the effect of formative assessment on student achievement: So much more is needed. Practical Assessment, Research \& Evaluation, 18(2). Retrieved from: http://pareonline.net/getvn.asp?v=18\&n=2

Miles, M. \& Huberman, M. (1994). Qualitative data analysis. London: Sage.

Mindes, G. \& Jung, L. (2015). Assessing young children ( $5^{\text {th }}$ ed). Upper Saddle River, NJ:Pearson.

Ministry of National Education. (2013). Education programs. Retrieved from http://ttkb.meb.gov.tr/www/ogretim-programlari/icerik/7

Mitchell, S. N., Reilly, R. C. \& Logue, M. E. (2009) Benefits of collaborative action research for the beginning teacher. Teaching and Teacher Education, 25(2). pp. 344-349.

Morrison. (2012). Early childhood education today (12 $2^{\text {th }}$ ed). Upper Saddle River, NJ: Pearson.

Pilten, P. (2001). Sınıf öğretmenlerinin ölçme ve değerlendirme alanındaki anlayış ve uygulamalarının değerlendirilmesi. Unpublished Master thesis, Selçuk University, Turkey.

Pine, G. J. (2008). Teacher action research: Building knowledge democracies. Sage.

Ryan, M., Taylor, M., Barone, A., Pesca, L.D., Durgana, S., Ostrowski, K., Piccirillo, T., \& Pikaard, K. (2017). Teacher as researcher, teacher as scholar, and teacher as leader, The New Educator, 13(2), 102-116.

Ruiz-Primo, M., \& Furtak, E. (2006). Informal formative assessment and scientific inquiry: Exploring teachers' practices and student learning. Educational Assessment, 11(3 \& 4), 205-235.

Sak, R., Tantekin-Erden, F., \& Morrison, G. S. (2018) Preschool teachers' beliefs and practices related to childcentred education in Turkey. Education 3-13, 46(5), 563-577.

Schappe, J. (2005). Early childhood assessment: A correlational study of the relationships among student performance, student feelings, and teacher perceptions. Early Childhood Education Journal, 33(3), 187193.

Seefeldt, C. (1998). Assessing young children. C. Seefeldt \& A. Galper, Continuing issues in early childhood education (pp. 314-338). New Jersey: Merrill

Seitz, H. (2008). The power of documentation in the early childhood classroom. YC Young Children, 63(2), 88.

Sezer, C. (2010). Okul öncesi öğretmenlerinin ölçme değerlendirmeyi kullanma düzeylerinin belirlenmesi. Unpublished PhD Thesis, Çanakkale Onsekiz Mart University, Çanakkale.

Shepard, L. A. (2000). The role of assesment in a learning culture. Educational Researcher 29(7), 4-14. 
Somekh, B. \& Zeichner, K. (2009). Action research for educational reform: Remodelling action research theories and practices in local contexts. Educational Action Research, 17(1), 5-21.

Stringer, E. (2007). Action research: A handbook for practitioners. Thousand Oaks, CA: Sage.

Tayler, C. (2012.) Learning in Australian early childhood education and care settings: changing professional practice, Education 3-13, 40(1), 7-18

Torrance, H., \& Pryor, J. (2001). Developing formative assessment in the classroom: Using action research to explore and modify theory. British Educational Research Journal, 27(5), 615-631.

Torrance, H. (2001). Assessment for learning: Developing formative assessment in the classroom, Education 313, 29(3), 26-32.

Twombly, S. (2014). When teaching interferes with learning: Balancing accountability with the unique needs of every child, The New Educator, 10(1), 44-52.

Wiliam, D. (2006). Formative assessment: Getting the focus right. Educational assessment, 11(3-4), 283-289.

Wininger, S. R., \& Norman, A. D. (2005). Teacher candidates' exposure to formative assessment in educational psychology textbooks: A content analysis. Educational Assessment, 10(1), 19-37.

Wortham, S. C. (2011). Assessment in early education (6 $6^{\text {th }}$ ed). New York: Pearson.

Yin, X. \& Buck, G. A. (2019). Using a collaborative action research approach to negotiate an understanding of formative assessment in an era of accountability testing. Teaching and Teacher Education, 80, 27-38. 